\title{
Improved learning accessibility and professionalism of teachers in remote areas through mentoring development of teaching materials based on Augmented Reality
}

\author{
Author \\ Sri Suryanti ${ }^{1}$, Deni Sutaji ${ }^{2}$, Yudhi Arifani ${ }^{3}$, Muyasaroh ${ }^{4}$, Muhammad Zamzamy ${ }^{5}$ \\ Correspondence \\ 1,3 Fakultas Keguruan dan Ilmu Pendidikan,Universitas Muhammadiyah Gresik \\ 4 Fakultas Agama Islam,Universitas Muhammadiyah \\ 2,5 Fakultas Teknik,Universitas Muhammadiyah Gresik \\ E-mail :1 ${ }^{\text {srisuryanti@umg.ac.id }}$
}

\begin{abstract}
:
The problem that underlies the Augmented Reality-based teaching material development assistance program for teachers in remote areas is located in the gap in the progress of the quality of education between remote and urban areas caused by demanding access to cities, and the lack of knowledge and understanding of teachers in developing materials innovative teaching by utilizing current technological advancements. Community service activities aim to produce innovative teaching materials based on Augmented Reality at Muhammadiyah 4 Daun Vocational School and MTs Muhammadiyah 5 Daun Sangkapura, Bawean Island. Bawean Island is located 80 miles or $135 \mathrm{~km}$ north of Java. The geographical location and transportation conditions connecting Bawean and Gresik islands are the main obstacles for teachers on Bawean island to follow the development of science and technology which results in the low quality of the learning process so that it lags behind the development of information technology.

Form of implementation of the program as a realization troubleshooting manifest in periodic and scheduled activities through a strengthening phase followed the concept of mobile learning needs analysis workshop, workshop material development, and implementation with the assistance of a team of stewards and continued application independently by the school in the implementation phase of using the steps Lesson Study as much as two cycles. The method used in the implementation of this activity is the method of discussion, workshops, and direct practice in class. Increased knowledge and ability of teachers teaching materials related to the development of innovative Augmented Realitybased and capable of producing the best practices in the implementation report the development of innovative teaching materials based Augmented Reality in learning in SMK Muhammadiyah 4 Daun and MTs Muhammadiyah 5 Daun Sangkapura, Bawean.
\end{abstract}

Keywords: Teaching Materials; Mobile learning; Augmented Reality; remote area. 


\section{Introduction}

\section{Situation Analysis}

Following the mandate of the Teacher Law and Lecturer Number 14 of 2005 in article 8 stated that the competencies that must be possessed by teachers are a) pedagogical competence; b) Personality competence; c) Social skill; d) Professional ability. Based on these four competencies, the core competencies that must be possessed by a teacher are: (1) developing a curriculum related to the field of learning that is taught, (2) organizing learning activities that educate, (3) developing learning materials that are taught creatively and (4) utilize information and communication technology to communicate and establish themselves. Based on the demands as well as these obligations a teacher is required to be able to compile innovative and creative teaching materials in accordance with the curriculum, the development of student needs and the development of information technology.

The problem of the selfdevelopment of educators is very crucial in advancing the education system in Indonesia. Selfdevelopment is very important, not only in physical aspects such as improving education levels, the number of training certificates, or professional teaching certificates (evidence of professional educators). However, self-development should also penetrate non-physical domains such as perspective, thinking paradigms, attitudes, habits, professionalism, and behavior in teaching

Teaching materials according to (Prastowo, 2013) are all materials (both information, tools and texts) that are arranged systematically, which displays a complete figure of the competencies that will be mastered by students and used in the learning process with the aim of planning and studying the implementation of learning, for example textbooks, modules, handouts, worksheets, models or models, audio teaching materials, interactive teaching materials and so on. According to (Ditendik, 2008) Interesting, effective, and efficient learning certainly requires innovative teaching materials. For this reason, a professional teacher is needed to be able to develop teaching materials that are innovative, varied, interesting, contextual, and under the needs of students.

The problem that arises is, many teachers at the school "stutter" and have difficulty when asked to compile their teaching materials, and more who use teaching materials made by others or factory-made in the learning activities they do (Sholeh, 2011). This is in line with opinions (Daryanto, 2012) although they know and are aware that the teaching materials they use are often not appropriate to the context and sociocultural situation of students. This is a phenomenon that is sad and alarming for the world of education in Indonesia.

Teachers also experienced these general problems at Muhammadiyah 4 Daun Vocational School and teachers at MTs Muhammadiyah 5 Daun Sangkapura, Bawean Island. Bawean Island is a remote island located in the Java Sea, about 80 miles or $130 \mathrm{~km}$ north of Java. Administratively, this island is included in the district of Gresik, East Java Province. Bawean Island consists of two areas, namely Sangkapura and Tambak sub-districts. The population is around 113,839 , with livelihoods as fishermen, farmers and most work as migrant workers in Malaysia and Singapore. The majority of ethnic Bawean residents are Bawean, Javanese, Madurese, Bugis, and Mandailing. The language of their daily speech is Bawean. 
From the city of Gresik to Bawean Island can be reached by air and sea travel. Air transportation is served by one small aircraft with a capacity of only 18 passengers and crew with a travel time of about 40 minutes. Flights only exist on Tuesdays and Thursdays through Surabaya's Juanda airport. Whereas the existing sea transportation is a fast boat with a travel time of about 3 hours at the cost of Rp 170,000 per person. In one week there are only two shipping days, namely every Wednesday and Sunday, besides that there is only one ship that serves the route. This will get worse if the weather is not favorable or during the big wave season the cruise is stopped for three or four weeks. As for the transportation of goods is an extraordinary open ship of products with a travel time of about 12 hours. Because of the high cost of fast boats, many Bawean citizens use cargo ships, crammed with merchandise and of course with a low level of safety. After arriving at the port of Bawean, the first to be found is Sangkapura District and will come at Tambak District with a travel time of 2 hours from Sangkapura.

Amenities highway in Bawean is not suitable for use because it has been badly damaged by the condition of the winding road follows the steep hillside surrounded by seas and deep ravines. Electric utilities already exist but can not be enjoyed equally up to the village in the interior, even in this area to frequent power outages due to interference bat. The distance from one village to another is quite far with inadequate road conditions. Transportation on the island of Bawean is a private vehicle that is used as a transportation and motorized becak. The cost of living in Bawean is prohibitive because all goods that cannot be produced in Bawean must be imported from Gresik so that the price of goods can reach twice the normal price.
On Bawean Island there are 18 SD / MI, 10 SMP / MTs and 4 SMA / MA both public and private. While the number of SD / MI teachers is 123 people, 215 teachers at SMP, and 83 teachers at SMA (Gresik Education Office, 2013). Educational facilities on Bawean Island are minimal, and there are still many school-age children in Bawean who cannot continue their education, especially in the remote villages of the foothills far from the highway with the reason of working to help their parents as fishermen, farmers, and migrant workers. Awareness of the importance of education is also deficient because they think that working as a migrant worker does not require a high level of education.

Based on data from the East Java provincial government, the number of children dropping out of school in 2015/2016 in Bawean Island in Gresik Regency is 59 students dropping out of elementary school, 54 students dropping out of MI, 86 students dropping out of junior high school and 94 students dropping out of MTs, 50 students dropping out of high school, 32 students drop out MA and 33 students dropped out of vocational school (Gresik Education Office, 2015). The high dropout rate is inseparable from the low awareness of the community on the importance of education.

The geographical location and transportation conditions that connect Bawean Island to the city of Gresik Regency are the main obstacles for teachers to follow the development of science and technology which results in the still-low quality of the learning process undertaken by teachers. Teachers on Bawean Island are rarely able to take part in training to improve their pedagogical or professional skills. The learning process in the classroom conducted by the teacher is still conventional. There are still many teachers who do not know IT. 
Information Technology that should be used by teachers in supporting the learning process in the classroom, such as teachers in the city. They cannot up to grade the knowledge they have because of the many obstacles so that they become teachers who are left behind. The government especially the Gresik Regency Education Office, is also still having difficulties in resolving the problem.

Based on the analysis of the situation, the team agreed to provide augmented reality-based teaching materials for teachers in remote areas of Bawean Island. Augmented reality is the merging of two-dimensional or threedimensional objects into a real threedimensional environment. Briefly, it can be interpreted the fusion of the virtual world with the real world. Augmented reality technology or often abbreviated as AR has been widely used in various subjects, such as Natural Sciences, Arts, and others. Some researchers have used AR technology into the world of education as has been done by Nugraha, Satoto, and Martono (2013) suggesting that piano chords using AR-based learning methods can make learning more fun. The use of AR technology is also used in learning to recognize human digestive organs as has been done by Saputro and Saputra (2015) suggesting that by using AR-based learning methods students are encouraged to know the names of organs and information from each of these digestive organs because they are presented in the form three-dimension. There are many other studies about AR in the world of education but it is unfortunate that not many people use AR technology in learning mathematics, even though this AR technology has the potential to be an innovation in the process of learning mathematics, especially in the matter of building flat fields.

\section{Methods}

This service program is carried out in the form of training (workshops) by prioritizing practices that produce products in the way of teaching materials based on Augmented Reality. Overall, the program implementation procedures are in the following order of activities:

- Strengthening the concepts of mobile learning and augmented reality

- Workshop and training on the development of teaching materials based on augmented reality

- Assistance in the implementation of the results of the development of teaching materials based on augmented reality

- Reflection on the results of training \& support in the event of teaching materials based on augmented reality

- Assistance in the follow up to the development of teaching materials based on augmented reality

- Implementation independently by the School.

\section{Partner Participation in Program Implementation}

Partners, in this case, MTs Muhammadiyah 5 Daun and SMK Muhammadiyah 4 Daun, have a significant role in the implementation of this activity, from preparation, execution, to monitoring and evaluation as well as follow-up activities. In development, the Partner School represented by the Principal, is involved in coordination with the program officer, followed by the determination of partner teachers engaged in the activity activities. In carrying out activities, the Principal will monitor the participation of teachers and even be involved in the activities. Thus the Principal will see the process of teacher 
activities involved in the service program starting from the beginning of the action until the end of the event.

The output of this activity is in the form of an augmented realitybased teaching material development product for learning in MTs and Vocational Schools. This teaching material will be published as a work of MTs Muhammadiyah 4 Daun teacher and Muhammadiyah 5 Daun Sangkapura Vocational School teacher in the form of an android application that is uploaded in the play store. Another output is the manual for the development of teaching materials based on augmented reality can be used by all teachers in the broader scope.

\section{Results and Discussion}

Initial Conditions of Implementation Development of augmented reality-based teaching materials in the Target Services Program School.

There are several activities arranged in the process of organizing the community service program. The overall activity is generally a form of synergy between program participants and the service team as facilitators/program assistants.

First, the earliest stage in organizing this service program is the coordination of the service team. This coordination is intended to finalize the program plan and preparation of various completeness of service programs, both administrative and technical aspects. From this initial coordination, it is hoped that the operationalization of all service program activities can be carried out as expected. This coordination involves the Head of the Sangkapura Regional Primary Education Office, Mr. Sihabbudin, M. Pd. As manager of a Muhammadiyah school in the Sangkapura area.

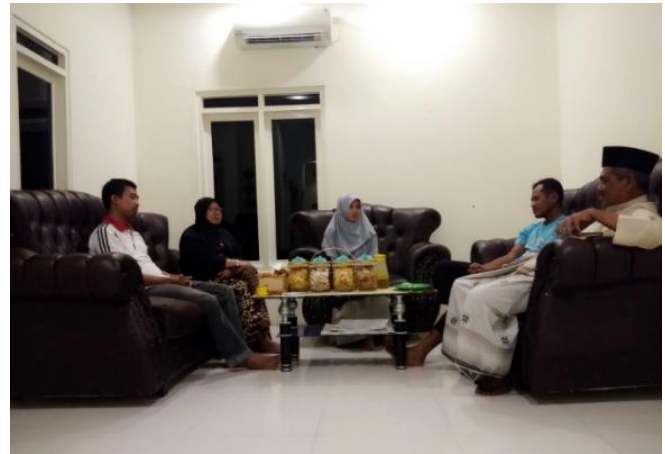

Figure 1. Community Service Team Discussion in Coordination of Preparation for Program Activities.

Second, the process of implementing community service programs in the form of socialization and strengthening the concepts of mobile learning and augmented reality. This strengthening is intended to introduce to partners about the products that will be developed in the service program later.

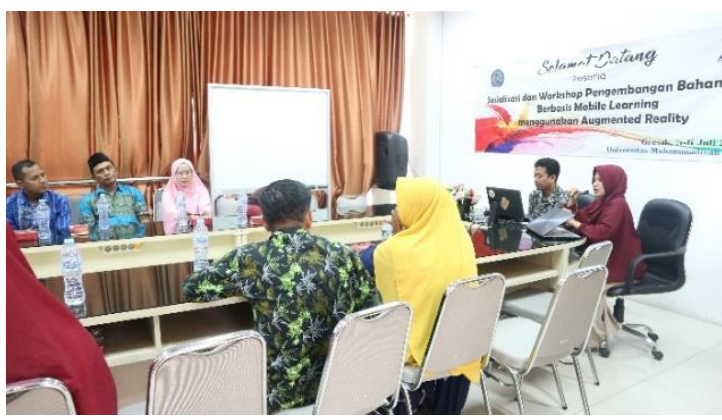

Figure 2. Socialization and strengthening of the concepts of mobile learning and augmented reality

Third, workshop activities with the practical orientation that produce augmented reality-based teaching material products. The form of organization chosen was seen as a practical activity to add and develop insights into the development of teaching materials based on augmented reality for teachers and was considered 
appropriate to answer the challenges of the current 4.0 industrial revolution.
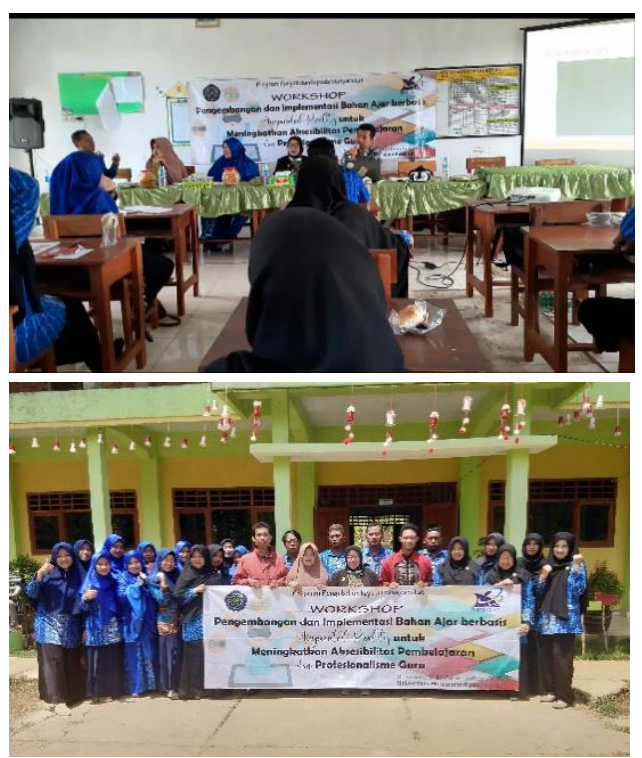

Figure 3. workshop activities

Fourth, the method of organizing community service programs in the form of workshops by prioritizing the principle of partnership makes the process take place interactively and dynamically develops constructively following the context of each participant, both individually and in school institutions. In carrying out activities, participants do it in stages under the pace of the process and their individual achievements. However, the whole took place in a controlled manner because of the presence of a facilitator/assistant. Thus the stages of achieving results are maintained by the targets set as planned.

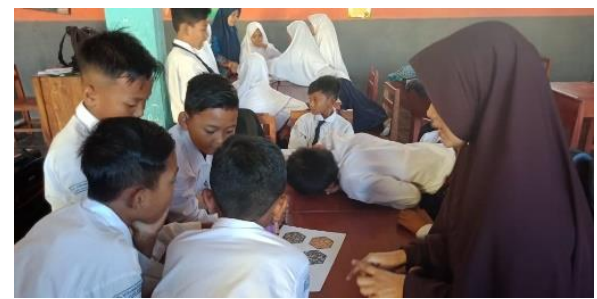

Figure 4. Implementations
An interactive and partnership process enables program participants to engage openly, actively, and dynamically progress. The issues faced honestly were raised and discussed together, both with other participants and with the facilitator. Thus, besides the problem can be overcome, what is built can also be a record and input for other participants in the implementation of the development of teaching materials based on augmented reality.

The form of program implementation as the realization of problem-solving is manifested in periodic and scheduled activities through: (1) socialization activities and strengthening the concepts of mobile learning and augmented reality; (2) Workshop and training on augmented reality-based teaching material development, (2) mentoring \& implementation of development products, Reflections on mentoring results and (4) Assistance in Follow-up Action Plans at MTs Muhammadiyah 4 Daun and Muhammadiyah 5 School Sangakapura as a school program partners and targets.

\section{Results of the Implementation of The Community Service Program}

The results of the implementation of this Community Service Program are teaching material products based on augmented reality for 7th-grade mathematics subject matter, and the products are as follows: 


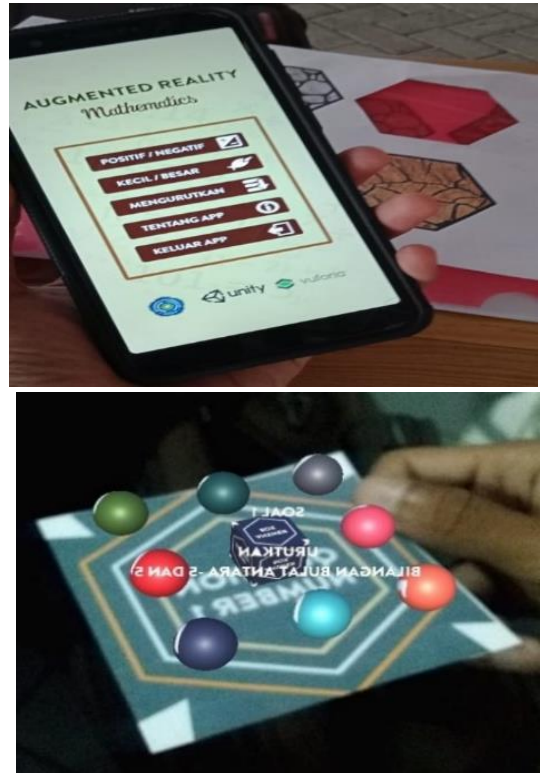

Figure 5. Display the face of the product development
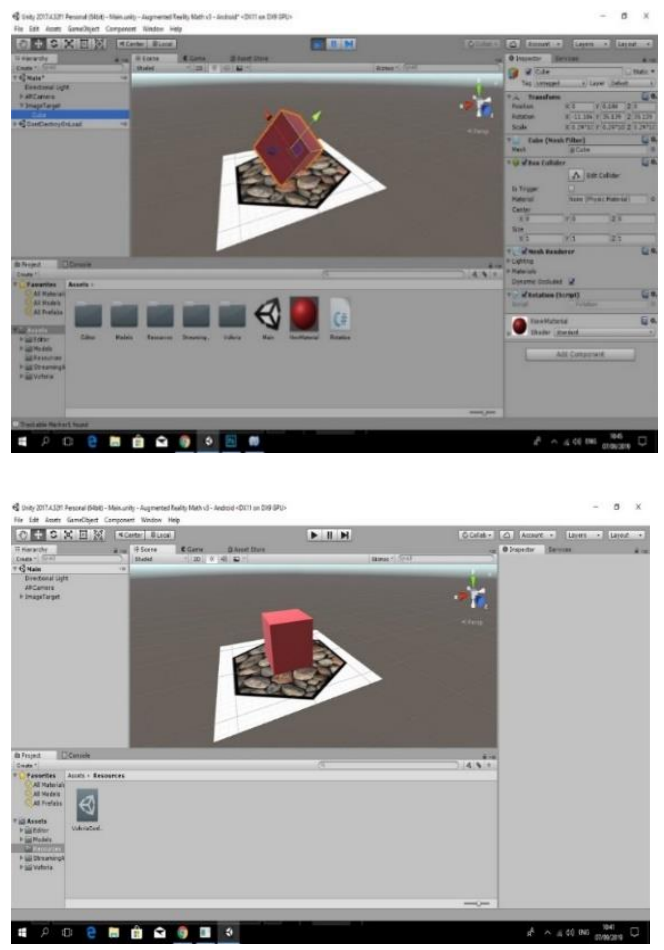

Figure 6. Image Target

Next is the result of evaluating the success of the program
Table 1. Achievement Level

\begin{tabular}{ccc}
\hline No & Aspect & $\begin{array}{c}\text { Achieve } \\
\text { ment }\end{array}$ \\
\hline 1 & $\begin{array}{c}\text { An understanding of } \\
\text { the concepts of } \\
\text { mobile learning and } \\
\text { augmented reality } \\
\text { Skills in using IT in } \\
\text { education } \\
\text { The ability to } \\
\text { develop teaching } \\
\text { materials oriented } \\
\text { towards the } \\
\text { industrial revolution } \\
\text { 4.0 } \\
\text { The ability to create } \\
\text { teaching materials } \\
\text { based on augmented } \\
\text { reality } \\
\text { The ability to } \\
\text { independently } \\
\text { implement product } \\
\text { development }\end{array}$ \\
\hline
\end{tabular}

Source: processed data

\section{Conclusions and Suggestions Conclusions}

Based on the whole process of implementing the PKM service program the development of teaching materials based on mobile learning using augmented reality for teachers in MTs Muhammadiyah 4 Daun and teachers of SMK Muhammadiyah 5 Daun Sangkapura, the following conclusions can be obtained. An increase in professional competence and teacher training in Mitra schools with indicators:

- The teacher understands the learning characteristics of the industrial revolution era of 4.0.

- The teacher understands the concepts of mobile learning and augmented reality

- Teachers have insight into the development of teaching materials based on augmented reality

- The teacher can implement knowledge by using the results of 
teaching materials developed

\section{Suggestions}

- For the development process, high computer specifications are required, so that if the partner has readiness in terms of this device, it will significantly support the success of the program.

- The process of developing teaching materials based on Augmented Reality requires quite a long time, so the results of the development have not reached the entire article. So it is suggested that further development is needed for the whole material in the future community service activities.

\section{References}

Anwar, K., \& Arifani, Y. (2016). Task based language teaching:

Development

CALL. International Education Studies, 9(6), 168.

Arifani, Y., \& Rosyid, H. (2016). Integrating Reading and Technology: The Development of ${ }^{\prime \prime}$ Pamanpintermu." English Language Teaching, 9(11), 13-28.

Direktorat Pembelajaran dan Kemahasiswaan. 2011. Pedoman Penulisan Makalah Lesson Study Untuk Seminar Exchange Experience, Dirjen Dikti, Kementrian Pendidikan Nasional, Jakarta.

Ibrohim. 2011. Lesson Study untuk Meningkatkan Kompetensi Pendidik, Kualitas Pembelajaran dan Perkembangannya Di Indonesia, Makalah disajikan dalam Seminar Nasional Lesson Study di UNTAD Palu, 28 Oktober 2011.

Jacob, S. M., \& Issac, B. (2008). Mobile Technologies and its Impact - An Analysis in Higher Education Context. International Journal of
Interactive Mobile Technologies, 10-18.

Jeane, Cathy. 2007. Lesson Study As A Form of Profesional Development for Teaching and Learning Mathematics. A Dissertation, New Mexico State University.

Karim, Abdul. 2010. Implementation of Lesson Study for Improving the Quality of Mathematics Instruction in Malang. Faculty of Mathematics and Science, State University of Malang.

Kirkley, Jamie. 2003. Principles for Teaching Problem Solving. Plato Learning, inc.

Sung, Y; Chang, K; \& Liu, T (2016). The effects of integrating mobile devices with teaching and learning on students' learning performance: A meta-analysis and research synthesis. Computers \& Education, Vol 94. p 252- 275

Suryanti, S. 2018. Pengembangan buku ajar Teori Ring berbasis IT dengan model project based learning untuk meningkatkan kemampuan penalaran mahasiswa. Laporan Hasil Penelitian Universitas Muhammadiyah Gresik.

Suryanti, S. (2018) Laporan Akhir Hibah Pembelajaran berbasis Blended Learning. Hibah SPADA Kemenristek DIKTI tahun 2018. Universitas Muhammadiyah Gresik.

Suryanti, S. \& Sutaji, D. (2018). The Effect of Using Ring Theory Mobile Application on Student Involvement and Reasoning Ability. Journal on Mathematics Education.

Tamim, R. M., Bernard, R. M., Borokhovski, E., Abrami, P. C., \& Schmid, R. F. (2011). What forty years of research says about the impact of technology on learning: a second-order meta-analysis and validation study. Review of 
Educational Research Vol 81, p 428.

Tangney, B. et al. (2010). MobiMaths: an approach to utilising smartphones in teaching mathematics.

Woodill, G. (2010). The mobile learning edge: Tools and technologies for developing your teams. McGraw Hill Professional. 